\title{
CROSSING THE CHASM IN SOFTWARE PROCESS IMPROVEMENT
}

\author{
Anna Börjesson \\ Fredrik Martinsson \\ Magnus Timmerås \\ Ericsson $A B$ and \\ IT University of Gothenburg \\ Gothenburg, Sweden
}

\begin{abstract}
Software process improvement (SPI) is a well-known approach to enhance software quality and business efficiency. The approach has been widely used, discussed, adopted and criticized within the software community since Watts Humphrey's introduction of SPI in 1989. SPI is a particular instance of diffusion of innovations. One challenging difficulty within diffusion of innovations is crossing the chasm between early adopters and early majority. To explore this issue in relation to SPI, we have studied an initiative implementing a new change request process and tool at the telecom company Ericsson $A B$ in Gothenburg, Sweden. An action research approach was adopted with the double purpose of supporting the SPI initiative toward success while at the same time learning about tactics that SPI change agents can adopt to successfully cross the chasm. The study identifies a tactic, the guerrilla tactic, that SPI change agents can use to successfully cross the chasm and it discusses lessons from practicing this tactic in relation to the SPI and diffusion of innovation literature.
\end{abstract}

Keywords Software process improvement, diffusion of innovations, the chasm, SPI change agent tactics

\section{INTRODUCTION}

Software process improvement (SPI) is a particular instance of diffusion of innovations. Both SPI and diffusion of innovations are approaches widely used in practice 
and elaborated in research. Several different models for how to organize and drive SPI work are available. The capability maturity model (Paulk et al. 1995), the IDEAL model (McFeeley 1996), and the plan-do-act-check cycle (Grady 1997) are some of the more familiar models. Far too many SPI efforts do, however, fail (Bach 1995; Bollinger and McGowan 1991; Börjesson and Mathiassen 2004b; Fayad and Laitinen 1997; Humphrey and Curtis 1991) and the indicated reasons are many. Established SPI and diffusion of innovation literature recognizes SPI change agents and their different tactics as important factors to avoid failure (Grady 1997; Humphrey 1989; Kautz et al. 2001; McFeeley 1996; Pries-Heje and Tryde 2001; Rogers 2003). Other reasons are the danger of not using structured approaches to change (Paulk 1999) such as the chasm (Moore 2002) and not recognizing and addressing it in the technology adoption curve (Rogers 2003). Moore (1999) claims that failure to diffuse a new technology can stem from not recognizing and understanding the challenges with the chasm. Moore identifies a special tactic for crossing the chasm called "down the bowling alley."

We have studied and participated in an SPI initiative at the telecom company Ericsson AB in Gothenburg, Sweden, over a 10 -month period. The SPI initiative focused on definition and implementation of a new change request solution for a product development unit consisting of 500 employees. The main question raised was, what tactics can SPI change agents use to cross the chasm? In the early stages of the SPI initiative, there was an idea by the SPI change agents driving the initiative to use a tactic where focus was put on establishing a trustworthy reference group and working closely with these people, both as a group and individually. The tactic, called the guerrilla tactic, was built on Moore's "down the bowling alley" tactic.

Delone and McLean (1992) observe that information technology use is the most frequently reported measure of IT implementation success and, therefore, it is used as an indicator for IT diffusion success. In accordance to this, the implementation and use of the new change request handling is used in this study as an indicator for SPI success. The new change request solution was successfully diffused into the organization and the chasm was crossed. The study explores the tactics that were adopted to achieve this. It discusses these in relation to Moore's (1999) ideas, and it discusses practical lessons learned in this particular SPI initiative with respect to crossing the chasm.

The study is presented as follows. The first section presents the theoretical context, mainly focusing on SPI change agent tactics and the chasm in the technology adoption curve. The next section describes the action-based research approach. In the fourth section, we present data from the SPI initiative according to Susman and Evered's (1978) cyclical action research approach and discuss the contributions of the research. Finally, our conclusions are presented in the fifth section.

\section{THEORETICAL CONTEXT}

This section presents the basic theoretical framework for this paper. First, we present SPI change agent tactics. Second, we review the technology adoption curve (Rogers 2003), the concept of the chasm (Moore 2002), and Moore's (1999) down-thebowling-alley strategy for crossing the chasm. 


\subsection{SPI Change Agent Tactics}

Humphrey (1989) stresses that enthusiastic, technically and politically capable, and dedicated resources with the management's confidence are necessary means to reach successful SPI. Humphrey calls these dedicated resources SPI change agents. Dedicated resources are needed to assure that practitioners overcome resistance, that practitioners are provided with adequate training and support, and that projects receive necessary consultation. SPI change agents need to use different tactics to accomplish these tasks. Several other SPI experts also recognize the need of SPI change agents to assure successful SPI. McFeeley (1996) stresses the importance of committing dedicated resources to drive the SPI work. Fowler and Levine (1993) identify the SPI change agent role and their tactics as one of five key factors for successful diffusion of an innovation. Pries-Heje and Tryde (2001) provide a practical framework for how SPI change agents can organize planning to assure successful process implementation. This strategy also includes other acknowledged implementation tactics (Eason 1988). PriesHeje and Tryde's work has been successfully adopted and used by Volvo IT in Gothenburg, Sweden (Andersson and Nilsson 2002).

We interpret the roles presented by Kautz et al. (2001) as tactics. In this light, the work of Kautz et al. can be seen as an SPI change agent that uses tactics from four different perspectives (technical expertise, facilitating participation, political agency, and individual therapy) to contribute more to the SPI result. The tactics do not preclude each other. The first tactic, technical expertise, provides insight to fully understand the problem area with help from a formal assessment. This tactic assumes that the organization can be completely controlled by introducing procedures and standards to perform work processes. The second tactic, facilitating participation, bases work on the assumption that the world is socially constructed. The focus is more on the change agent performing a consulting and facilitating role where the members of the organization discover the improvements and solutions themselves. The third tactic, political agency, resolves structural conflicts among different stakeholder groups in the organization. The change agent, using the tactic political agency, strives for change through influencing the tensions and contradictions among organizational members. The change agent believes in radical change. The fourth tactic, individual therapy, assumes that reality is socially constructed. The change agent, using this tactic, works with the different individual subjects' attitudes and opinions, because the agent recognizes that the world is created by the individual.

SPI has been viewed by many of these authors as a particular instance of diffusion of innovations (Rogers 2003). Humphrey, McFeeley, and Grady all agree and argue that SPI will not happen if dedicated people do not drive the change. This is also further elaborated and emphasized by Börjesson and Mathiassen (2004b), who point out several different SPI change agent tactics to be used to accomplish successful SPI. Rogers claims that SPI change agents would not be needed in the diffusion of innovations if there were no social and technical chasms between the change agency and the client system. This is, however, not the case and Rogers defines five different generalizations (i.e., SPI change agent tactics) for how SPI practitioners can interact with the clients to achieve positive diffusion effects. The success of the SPI change agent in securing the adoption of processes by clients is positively related to the following: 
- The extent of the SPI change agent's effort in contacting clients

- Client orientation, rather than a change agency orientation

- The degree to which a diffusion program is compatible with clients' needs

- Empathy with clients

- Credibility in the clients' eyes

\subsection{Crossing the Chasm}

It is well established within SPI literature that there is a gap between acquired and deployed technologies (Fichman and Kemerer 1999) and several theories have been presented to explain reasons for this gap (Abrahamsson 2001; Börjesson and Mathiassen 2004b; Weinberg 1997). Moore's (2002) chasm emphasizes the gap. The chasm framework was originally developed to understand marketing and deployment of hightechnology products over a population of profit-making firms. The chasm has also been discussed and used as an overall framework for understanding change (Paulk 1999). Paulk argues that the use of structured tactics to cope with change increases the likelihood of successful change. Moore's (1999) suggestion for how to cross the chasm, "down the bowling alley," is such a tactic. Moore's chasm is built upon Rogers' recognized technology adoption curve, which consists of five different groups of people, each group having its specific profile (see Figure 1). The first group, innovators, tends to seek out the new technology before formal marketing. The innovators usually are very technology focused. The second group, early adopters, accepts new products very early in the technology life cycle. The early adopters find it easy to imagine, understand, and appreciate the potential benefits with the new technology. The third group, early majority, is driven by a strong sense of practicality. The early majority wants well-established references from relevant market segments before committing themselves. The fourth group, late majority, shares all of the concerns of the early majority, but they do not feel comfortable in their ability to manage the new technology. They wait until a new technology has become a well-established standard. The fifth and final group, laggards, simply do not want anything to do with the new technology. When they accept a new technology, they probably do not know it is there.

One main idea when diffusing an innovation is to create a bandwagon effect where each convinced group can be used as a reference for the next group to keep momentum when marketing of a new technology (Rogers 2003). Between any of these groups, there is a gap. This gap symbolizes the difficulty any group will have in accepting a new technology if it is presented in the same way as it was to the group to its immediate left (Moore 2002). The important gap is the gap between early adopters and early majority (see Figure 1), which is called the chasm (Moore 2002). Moore claims that this chasm is extremely dangerous if it goes unrecognized. The innovators and the early adopters are prepared to bear with the bugs and glitches that the new technology entails. The early majority wants technology to enhance, not overthrow, the established ways of working. Because of these incompatibilities, the early adopters do not make a good reference for the early majority. The early majority does, however, need good references to assure a minimal disruption of the established way of working. Moore (2002) defines this as a catch-22 problem. 


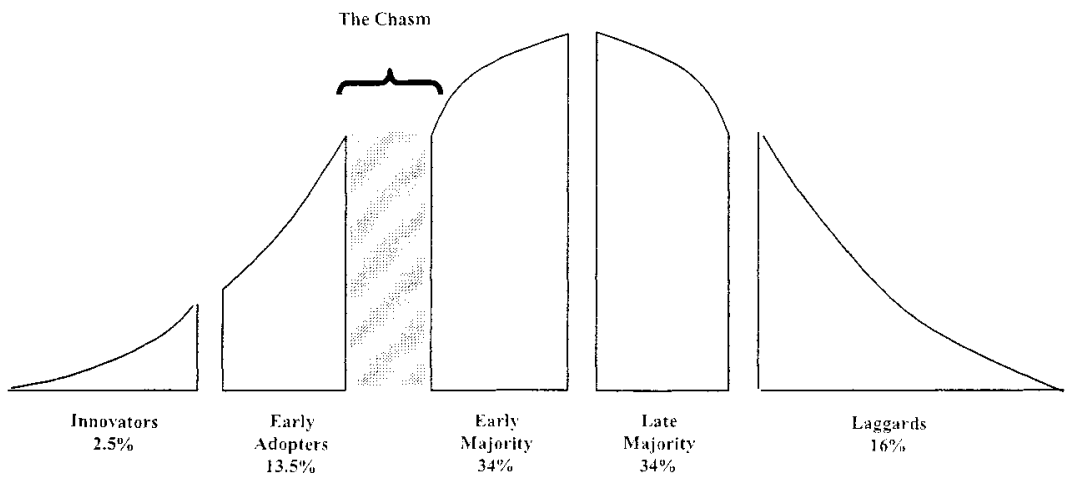

Figure 1. The Technology Adoption Curve (Rogers 2003) and the Chasm (Moore 2002)

To solve the catch-22, Moore (1999) presented his down-the-bowling-alley tactic for crossing the chasm. Each market niche, or group of would-be adopters, is represented by a bowling pin and the goal is to strike down one pin so that it helps to knock the next one over. In this way, momentum is built up as more and more pins are knocked over by each other. Moore claims that the selection of pins to target is an important task. The initial selected pins should meet two criteria; the would-be adopters should have a compelling need for the solution, and competition should be scarce in that area. There is also a need for applying a customer-oriented tactic. The innovation supplier ensures that they can deliver the whole product to the selected target (i.e., instead of trying to satisfy the requirements of the whole market, focus is put on meeting one target customer's expectations). Moore identifies the whole product as the bare minimum requirements one specific customer has to purchase the innovation. Momentum is built up through first selecting the pins within the same market segment with the same whole product needs, and then further developing the product to reach new market segments. At this point, the chasm has been crossed and the early majority market is about to be penetrated.

\section{RESEARCH APPROACH}

This SPI initiative had the dual goal of both improving the change request handling and understanding what tactics SPI change agents can use to cross the chasm and assure successful SPI. Mathiassen's (2002) collaborative practice research (CPR) supports the possible realization of this dual goal. Another important part of CPR is the insider and outsider perspective (Bartunek and Louis 1996). The authors of the current study have been working within Ericsson in the SPI unit. Two of them have been driving the initiative as SPI change agents and have taken the insider role (i.e., they have been directly involved in action). The third author has been responsible for the initiative, but 
has taken the outsider role through regular analysis, discussions with the SPI change agents, reflection, and interviews with SPI initiative participants. The intiative has also been discussed, analyzed, and reflected upon in the monthly SPI forum (Börjesson 2004).

The study is based on action research (Baskerville and Pries-Heje 1999; Davison et al. 2004; Galliers 1992) with a focus on understanding what tactics SPI change agents can use to cross the chasm and, by doing so, assuring SPI success. The research question is, what tactics can SPI change agents use to cross the chasm? Baskerville and Pries-Heje (1999) argue that the fundamental contention of action research is that a complex social process can be studied best by introducing changes into that process and observing the effects of these changes. Recent research by Davison et al. (2004) elicited a set of five principles and associated criteria to ensure and assess both rigor and relevance of canonical action research (CAR). The term canonical is used to formalize the association with the iterative, rigorous, and collaborative process-oriented model developed by Susman and Evered (1978). Susman and Evered's model has been widely adopted in the social sciences and, hence, has gained "canonical status" (Davison et al. 2004). The five proposed principles and the adoption of these in this study are described in Table 1.

Both the study and the structure of the paper have followed the cyclical action research approach by Susman and Evered, including the five phases of diagnosing (identifying the problem), action planning (considering alternative courses of action for solving the problems), action taking (selecting a course of action), evaluating (studying the consequences of the actions taken), and specifying learning (identifying general indicators for SPI success).

Table 1. The Principles of CAR (Davison et al. 2004) and its Adoption in This Study

\begin{tabular}{|l|l|}
\hline \multicolumn{1}{|c|}{ Principle } & \multicolumn{1}{c|}{ Adoption in This Study } \\
\hline $\begin{array}{l}\text { The principle of the } \\
\text { researcher-client } \\
\text { agreement (RCA) }\end{array}$ & $\begin{array}{l}\text { The researchers and clients are the same individuals. One } \\
\text { of the three researchers has taken the academic role through } \\
\text { the commitment to an ongoing industrial Ph. D. program. }\end{array}$ \\
\hline $\begin{array}{l}\text { The principle of the } \\
\text { cyclical process } \\
\text { model (CPM) }\end{array}$ & $\begin{array}{l}\text { The study used Susman and Evered's (1978) cyclical action } \\
\text { research method. }\end{array}$ \\
\hline $\begin{array}{l}\text { The principle of } \\
\text { theory }\end{array}$ & $\begin{array}{l}\text { Established theories as the technology adoption curve } \\
\text { (Rogers 2003), the chasm (Moore 2002) and "down the } \\
\text { bowling alley" (Moore 1999) are used. }\end{array}$ \\
\hline $\begin{array}{l}\text { The principle of } \\
\text { change through } \\
\text { action }\end{array}$ & $\begin{array}{l}\text { One of the main goals of the study is to change the current } \\
\text { way of working and to improve practice. CPR (Mathiassen } \\
\text { 2002) is adapted. }\end{array}$ \\
\hline $\begin{array}{l}\text { The principle of } \\
\text { learning through } \\
\text { reflection }\end{array}$ & $\begin{array}{l}\text { Meetings for reflections on the ongoing progress have been } \\
\text { regularly pianned and executed. Also, the initiative has } \\
\text { been regularly analyzed and reflected upon in the monthly } \\
\text { SPI forum (Börjesson 2004). }\end{array}$ \\
\hline
\end{tabular}


Table 2. Data Collected Throughout the Initiative

\begin{tabular}{|l|l|l|}
\hline$\#$ & \multicolumn{1}{|c|}{ What } & \multicolumn{1}{c|}{ Explanation } \\
\hline 1 & $\begin{array}{l}\text { Direct } \\
\text { involvement }\end{array}$ & $\begin{array}{l}\text { All three authors have been directly involved or respon- } \\
\text { sible for the management and outcome of the SPI initia- } \\
\text { tive. This participation gives primary access to the } \\
\text { organization, personal opinions, coffee break discussion, } \\
\text { etc. that cannot be reached in any other way. }\end{array}$ \\
\hline 2 & SPI initiative data & $\begin{array}{l}\text { The two SPI change agents driving the initiative col- } \\
\text { lected data about reference group meetings (time, } \\
\text { participants, disagreements, decisions, outcome, etc.) }\end{array}$ \\
\hline 3 & $\begin{array}{l}\text { Participatory } \\
\text { observations }\end{array}$ & $\begin{array}{l}\text { The author taking the outsider role participated in some } \\
\text { reference group meetings to observe and reflect. }\end{array}$ \\
\hline 5 & $\begin{array}{l}\text { SPI forum content } \\
\text { reflections }\end{array}$ & $\begin{array}{l}\text { The papers and ongoing SPI initiatives that were } \\
\text { studied, discussed, and reflected upon. }\end{array}$ \\
\hline 6 & $\begin{array}{l}\text { SPI unit survey } \\
\text { 2003 and 2004 } \\
\text { were written down and stored by one of the authors on } \\
\text { the internal SPI unit Web. }\end{array}$ & $\begin{array}{l}\text { 60 questions with six scale answers were asked through } \\
\text { a Web questionnaire in the yearly SPI unit survey in } \\
\text { 2003 and 2004 to all software engineers in the } \\
\text { development unit. }\end{array}$ \\
\hline 7 & $\begin{array}{l}\text { Tool data } \\
\text { participants in the } \\
\text { reference group. }\end{array}$ & $\begin{array}{l}\text { Access to data in the tool such as change request regis- } \\
\text { trations, who and how many entering data in the tool, } \\
\text { and how the change requests were managed according to } \\
\text { the process. } \\
\text { interview. } \\
\text { lach interview lasted for 30 minutes (occasionally }\end{array}$ \\
\hline
\end{tabular}

The authors collected data for 10 months throughout the initiative as summarized in Table 2. Triangulation of data (Y in 1994) has been important to avoid bias and to secure validity of the research. The combination of many different data sources has made triangulation possible.

\section{ACTION LEARNING}

The SPI initiative follows Susman and Evercd's (1978) five phases. The first phase identifies and defines the problem with the current change request handling situation and the difficulties with assuring SPI implementation and use. The second phase describes the plan to solve the problem by implementing a new solution for change requests and 
Table 3. The Change Request Process and Tool Situation in Late 2003

\begin{tabular}{|l|l|l|}
\hline \multicolumn{1}{|c|}{ CCB } & \multicolumn{1}{c|}{ Process } & \multicolumn{1}{c|}{ Tool } \\
\hline Development project A & Project specific process A & No tool (spreadsheet A) \\
\hline Development project B & Project specific process B & No tool (spreadsheet B) \\
\hline Development project C & Project specific process C & Local version C \\
\hline Unit X & Unit specific process X & Local version X \\
\hline Unit Y & Unit specific process Y & No tool (spreadsheet Y) \\
\hline
\end{tabular}

it also describes a new tactic to address the difficulties with process implementation and use. The third phase describes which actions were taken according to the plan. The fourth phase discusses the evaluation of the actions taken. Finally, phase five discusses general indicators for successful SPI in relation to the theoretical context presented in the second section.

\subsection{Diagnosing}

The software development unit studied develops and maintains parts of $3 \mathrm{G}$ mobile networks. It is located in Gothenburg, Sweden, and has approximately 500 employees. There is an SPI group, responsible for driving SPI initiatives, consisting of six people. In late 2003 , the change request procedures were identified as a major risk for development projects and the organization as a whole. Over 150 employees were directly affected by these procedures. The degree and pace of changes within software organizations have increased over the past years as indicated by the notions of fast-moving software organizations (Baskerville et al. 2001; Börjesson and Mathiassen 2004a; Holmberg and Mathiassen 2001) and radical IT-based innovations (Lyytinen and Rose 2003). Software organizations and their ongoing development projects constantly need to react to new or changed customer requirements as a result of a changing business environment. The studied organization has several different change control boards (CCB), supporting either a development project or a specific organizational unit with management of the change requests. All CCBs used different processes for changerequest handling and most of the processes lacked tool support. Table 3 shows the change-request process and the tool situation in late 2003.

A number of problems were identified. Each CCB had its own process for changerequest handling, and its own way of storing the data. Each time a CCB was set up, effort was spent on defining these issues. Change requests that needed to be handled by more than one CCB became very complex from an administration and follow-up point of view, with the risk of loosing track of decisions and information when a change request moved between the CCBs.

With the exception of the complexity of the improvement initiative, there was an identified problem regarding successful deployment of new solutions. Through extensive SPI initiative participation, theory studies, discussion, and reflection (Börjesson 2004), the SPI unit acknowledged a major difficulty when starting a wider deployment 
Table 4. Data from SPI Unit Survey 2003 and 2004

\begin{tabular}{|l|c|c|c|c|}
\hline \multirow{2}{*}{$\begin{array}{l}\text { How important is it that you participate to } \\
\text { assure successful SPI? }\end{array}$} & \multicolumn{2}{|c|}{$\begin{array}{c}\text { Not } \\
\text { Important }\end{array}$} & \multicolumn{2}{|c|}{ Important } \\
\cline { 2 - 5 } & $\mathbf{2 0 0 3}$ & $\mathbf{2 0 0 4}$ & $\mathbf{2 0 0 3}$ & $\mathbf{2 0 0 4}$ \\
\hline I am the leader of the process work & $72 \%$ & $71 \%$ & $28 \%$ & $29 \%$ \\
\hline $\begin{array}{l}\text { I am a part of the group defining the new way of } \\
\text { working }\end{array}$ & $40 \%$ & $38 \%$ & $60 \%$ & $62 \%$ \\
\hline $\begin{array}{l}\text { I give feedback to the new way of working in } \\
\text { order to get it good enough }\end{array}$ & $16 \%$ & $14 \%$ & $84 \%$ & $86 \%$ \\
\hline
\end{tabular}

of a new or changed process (Börjesson and Mathiassen 2004b; Fichman and Kemerer 1999; Humphrey 1989: Weinberg 1997). Users of new practices did not accept new solutions in the same way as the SPI change agents driving the initiatives. Many of the potential users were driven by a strong sense of practicality and they wanted clear proof that the new solution would be beneficial for them.

Furthermore, data from two consecutive SPI surveys show that people want to be involved to assure a successful SPI (see Table 4). Almost 3 out of 10 employees wanted to lead the work. More than 6 out of 10 employees wanted to be a part of defining the new way of working. More than 8 out of 10 wanted to review the new way of working to assure it was good enough. It is, however, practically impossible to fulfill these desires in a large organization. This data indicates the importance of having a trustworthy reference group on which people can rely.

\subsection{Action Planning}

In late 2003, the organization decided to start an SPI initiative to improve the change-request process and tool situation. The plan was to define a new process (based on previous experience) in close collaboration with the development project just starting up and the unit controlling the product features on an overall level. The other CCBs would align as new development projects started and the old one finished its release. There was a decision to use the tool ClearQuest. This was a natural choice as this was Ericsson's choice as a corporation for change-request handling. Two of the CCBs had used ClearQuest as a support tool before and ClearQuest has connections to other tools already used in the organizations (such as RequisitePro and ClearCase).

In parallel, the SPI unit decided to use previous learning on how to manage successful SPI initiatives (Börjesson and Mathiassen 2004b). The SPI change agents dedicated to the SPI initiative also decided to try out a new tactic to make users accept the solution faster. As the identified problems were closely related to the chasm (Moore 2002), the down-the-bowling-alley tactic was used for setting up the guerrilla tactic The guerrilla tactic consists of two main parts: choosing a dedicated reference group with a compelling need for the solution and having a tactic for close collaboration between the SPI change agents and the reference group. The SPI initiative will benefit from having a reference group upon which all potential users can rely. The reference 
group should consist of people driven by a sense of practicality who will become natural references for the majority of users. The reference group needs to consist of members that cover all affected organizational areas. The typical member of the reference group must be experienced in the specific practice, understand the big picture, and be well known and respected in order to facilitate the deployment of the SPI initiative. The SPI change agents, representing the group of people that casily understand and appreciate the potential benefits of the new practice, should work in close collaboration with the reference group to become their natural reference. The SPI change agents should influence the most strategic individuals in the reference group in order to get commitment at reference group decision meetings and to elaborate ideas with its members.

The collaboration between the reference group and the SPI change agents can be described as influencing a group by influencing its core members. The tactic for close collaboration consists of SPI change agents who personally brief and discuss upcoming decisions with some of the members of the reference group in between reference group decision meetings. The member that needs to be addressed before a decision meeting varies, since that is dependent on the decisions to be discussed in the upcoming meeting. Collaboration with strategic reference group members addresses problems and uncertainties but also new ideas for how things should be solved before the actual decision meeting takes place.

The first bowling pin in the guerrilla tactic is the reference group (see Figure 2). This first pin will help to knock the next one over (i.e., get the other users to use the new solution). It is, therefore, extremely important to choose and collaborate with the reference group in a way that ensures their commitment and dedication to the solution.

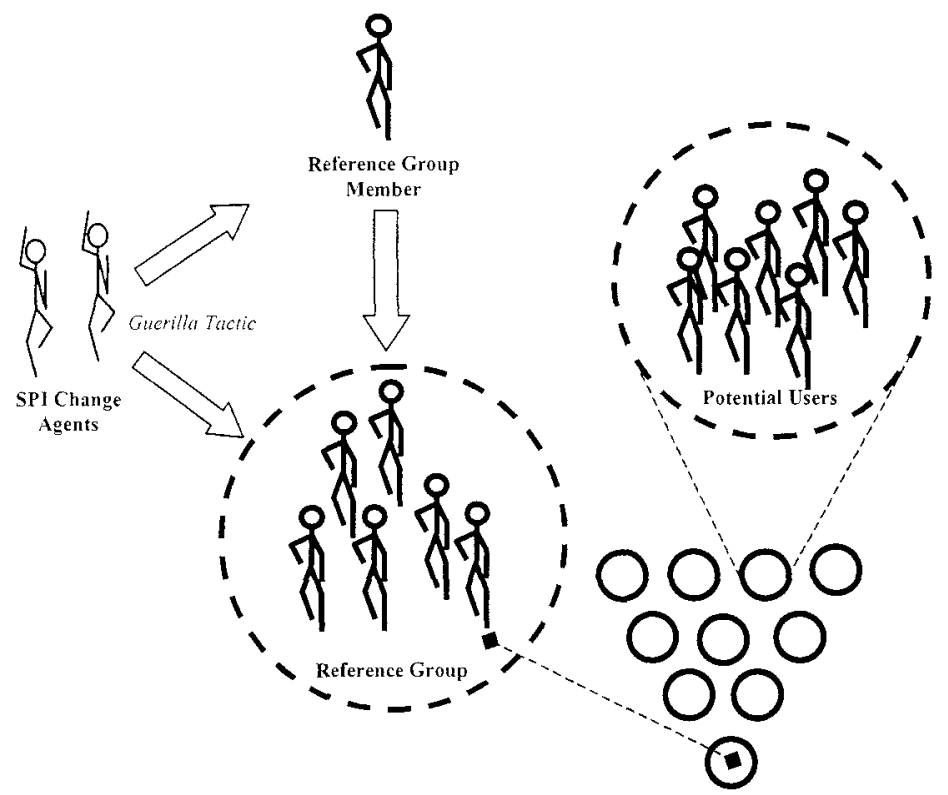

Figure 2. SPI Change Agents Using the Guerrilla Tactic 


\subsection{Action Taking}

A first action was to set up the reference group. A number of strategic people (nine individuals) responsible for or involved in the CCB work were asked by the SPI change agents to participate in the reference group. In parallel, the SPI change agents learned how to master the ClearQuest tool for the advanced technical development of the solution. One important success factor for accomplishing high process push is to have not only committed SPI change agents, but also competent SPI change agents (Börjesson 2004; Humphrey 1989; McFeeley 1996).

Between reference group meetings, the SPI change agents addressed strategic individuals in the reference group in order to prevent unnecessary disagreements and thus improve the solution. Events that triggered the SPI change agents to address a strategic individual could be if they believed that this person had in-depth knowledge, was poorly informed, felt overrun, or if they believed this person could impact the other people in the group to understand the big picture. Table 5 shows date and purpose, meeting preparations that were made between reference group meetings and the outcome of these meetings.

In early May, the new change request solution was presented and deployed. The SPI change agents conducted a number of courses to all potential users and reference group members participated in each course. The reference group members could defend and explain the solution and, as they were active users of the new solution, they became well-established references. The SPI change agents also conducted start-up meetings for the affected CCBs in order to support them in the early phases of introducing the new work methods. Again, reference group members played a central deployment role as they both were regular members of the CCBs and had been a part of the SPI initiative. Finally, as the SPI change agents were phased out of deployment activities, the reference group members stayed current in their regular roles, where use of the new solution was natural. In these roles, the reference group members could continue the day-to-day deployment and support the new solution

\subsection{Evaluating}

In mid-June 2004, eight active users were interviewed about their experiences and opinions concerning the SPI initiative and solution in order to further understand how the guerrilla tactic affected the outcome of the initiative. This tactic was unknown to the reference group at the time the interviews were conducted. The active users represented the three target CCBs, CCB chairmen, project managers, and senior engineers working with change requests in their daily work. The results of the interviews are summarized in Table 6.

When the solution was released, the reference group members and CCB members were immediately given access to the tool. Table 7 shows the growth of users entering data in the tool and the amount of data in the database. The numbers in the table are accumulated from the date (May 10,2004) the database was opened for use. The numbers show individuals that actually updated information in the tool. It has not been possible to measure users only reading information 
Table 5. Reference Group Meeting Data

\begin{tabular}{|l|l|l|}
\hline \multicolumn{1}{|c|}{$\begin{array}{l}\text { Reference Group } \\
\text { Meeting }\end{array}$} & Meeting Preparations & \multicolumn{1}{c|}{ Meeting outcome } \\
\hline $\begin{array}{l}\text { \#1: 2004-01-15 } \\
\text { Present time plan and } \\
\text { purpose of the reference } \\
\text { group and the change } \\
\text { request handling }\end{array}$ & $\begin{array}{l}\text { The SPI change agents } \\
\text { collaborated individ- } \\
\text { ually with four refer- } \\
\text { ence group members }\end{array}$ & $\begin{array}{l}\text { Agreement and necessary } \\
\text { decisions taken. }\end{array}$ \\
\hline $\begin{array}{l}\text { \#2: 2004-01-30 } \\
\begin{array}{l}\text { Present overall change } \\
\text { request solution and } \\
\text { concept }\end{array}\end{array}$ & $\begin{array}{l}\text { No collaborations } \\
\text { performed }\end{array}$ & $\begin{array}{l}\text { No agreement. Most of the } \\
\text { reference group members } \\
\text { had their own opinion } \\
\text { about a potential solution. }\end{array}$ \\
\hline $\begin{array}{l}\text { \#3: 2004-02-06 } \\
\text { Present overall change } \\
\text { request solution and } \\
\text { concept }\end{array}$ & $\begin{array}{l}\text { The SPI change agents } \\
\text { collaborated individ- } \\
\text { ually with five refer- } \\
\text { ence group members }\end{array}$ & $\begin{array}{l}\text { Agreement and necessary } \\
\text { decisions taken. }\end{array}$ \\
\hline $\begin{array}{l}\text { \#4: 2004-02-20 } \\
\text { Present change request } \\
\text { process and detailed } \\
\text { solution }\end{array}$ & $\begin{array}{l}\text { The SPI change agents } \\
\text { collaborated individ- } \\
\text { ually with three refer- } \\
\text { ence group members }\end{array}$ & $\begin{array}{l}\text { Agreement (after smaller } \\
\text { adjustments) and necessary } \\
\text { decisions taken. }\end{array}$ \\
\hline $\begin{array}{l}\text { \#5: 2004-03-05 } \\
\text { Peer review of detailed } \\
\text { solution, two new partici- } \\
\text { pants in the reference } \\
\text { group }\end{array}$ & $\begin{array}{l}\text { No collaborations } \\
\text { performed }\end{array}$ & $\begin{array}{l}\text { No agreement. The two } \\
\text { new reference group } \\
\text { members objected, as they } \\
\text { did not fully understand } \\
\text { the earlier agreements. }\end{array}$ \\
\hline $\begin{array}{l}\text { F6: 2004-03-12 } \\
\text { solutional review of detailed } \\
\text { of tool interface }\end{array}$ & $\begin{array}{l}\text { The SPI change agents } \\
\text { collaborated individ- } \\
\text { ually with seven refer- } \\
\text { ence group members }\end{array}$ & $\begin{array}{l}\text { Agreement (after smaller } \\
\text { adjustments) and necessary } \\
\text { decisions taken. }\end{array}$ \\
\hline
\end{tabular}

The SPI initiative was carried out according to the time plan. Six reference group meetings were held within the planned time frame. The rollout of the solution was originally planned to match the need of a new engineering project in week 18 , but as the engineering project was a few weeks late, the rollout of the new change request solution was moved to week 21.

This SPI initiative aimed to cover the entire organization; however, all employees are not required to work with change request handling. The calculation of the total target group is based on the main technical stakeholders (project managers and requirements engineers, approximately 90 employees) having an 80 percent usage and peripheral technical stakeholders (ciesign and test engineers, approximately $325 \mathrm{~cm}$ ployees) having a 25 percent usage. The 80 -percentage number is based on that most, but not all, main technical stakeholders are working with change requests, while the 25 percentage number is based on the prerequisite that only team leaders and senior engi- 
Table 6. Compiled Results of the Interviews

\begin{tabular}{|c|l|c|c|c|c|}
\hline \multicolumn{1}{|c|}{ Questions } & \multicolumn{1}{|c|}{ Yes } & No & $\begin{array}{c}\text { Not } \\
\text { Applicable }\end{array}$ & $\begin{array}{c}\text { Positive } \\
\text { Answers }\end{array}$ \\
\hline 1 & The result was generally positive & 6 & 2 & 0 & $75 \%$ \\
\hline 2 & $\begin{array}{l}\text { The decisions were generally handled } \\
\text { in a positive way }\end{array}$ & 6 & 1 & 1 & $75 \%$ \\
\hline 3 & $\begin{array}{l}\text { The SPI change agents' process push } \\
\text { was generally positive }\end{array}$ & 5 & 1 & 2 & $63 \%$ \\
\hline 4 & $\begin{array}{l}\text { The rollout was generally considered as } \\
\text { positive }\end{array}$ & 7 & 0 & 1 & $88 \%$ \\
\hline 5 & $\begin{array}{l}\text { The users' response have generally } \\
\text { been positive }\end{array}$ & 6 & 2 & 0 & $75 \%$ \\
\hline 6 & $\begin{array}{l}\text { The attitude is, in the end, generally } \\
\text { positive }\end{array}$ & 6 & 2 & 0 & $75 \%$ \\
\hline 7 & $\begin{array}{l}\text { It was generally positive with a tight } \\
\text { time schedule }\end{array}$ & 5 & 1 & 1 & $71 \%$ \\
\hline 8 & $\begin{array}{l}\text { The result was generally received } \\
\text { positively }\end{array}$ & 5 & 1 & 2 & $63 \%$ \\
\hline
\end{tabular}

Table 7. Active Users and Data in the Change Request Database

\begin{tabular}{|l|c|c|c|c|}
\hline \multicolumn{1}{|c|}{ Measurement } & $\begin{array}{l}\mathbf{2 0 0 4 -} \\
\mathbf{0 6 - 0 2}\end{array}$ & $\begin{array}{c}\mathbf{2 0 0 4 -} \\
\mathbf{0 7 - 0 5}\end{array}$ & $\begin{array}{c}\mathbf{2 0 0 4 -} \\
\mathbf{0 9 - 0 2}\end{array}$ & $\begin{array}{c}\mathbf{2 0 0 4 -} \\
\mathbf{1 0 - 0 4}\end{array}$ \\
\hline $\begin{array}{l}\text { Number of change requests submitted } \\
\text { since the start }\end{array}$ & 24 & 99 & 170 & 258 \\
\hline $\begin{array}{l}\text { Number of unique users having up- } \\
\text { dated change requests since the start }\end{array}$ & 19 & 43 & 54 & 65 \\
\hline
\end{tabular}

Table 8. Distribution of Potential Users Between Groups

\begin{tabular}{|l|c|c|}
\hline \multicolumn{1}{|c|}{ Group } & $\begin{array}{c}\text { Percentage according to } \\
\text { Rogers }\end{array}$ & $\mathbf{1 5 2 \times \text { Rogers' percentage }}$ \\
\hline Innovators & $2.5 \%$ & 4 \\
\hline Early Adopters & $13.5 \%$ & 20 \\
\hline Early Majority & $34 \%$ & 52 \\
\hline Majority & $34 \%$ & 52 \\
\hline Laggards & $16 \%$ & 24 \\
\hline Total sum & $100 \%$ & $152(88 \times 08+326 \times 0.25)$ \\
\hline
\end{tabular}


neers are working with change requests. Groups that are not expected to work with change request handling have not been counted (approximately 100 employees). Table 8 shows the distribution of the population of expected change request users and what role they take in Rogers' diffusion of innovation curve.

\subsection{Learning}

As indicated from the interviews (Table 6) and tool measurements (Table 7), the SPI initiative was successful in implementation and use. In all, 75 percent of the interviewees believed the initiative was successful. Also, within a period of 5 months period from the start, nearly half of all potential users had accessed and entered data in the change request tool. The main question now is to understand what effects the guerrilla tactic had on this positive outcome.

The two SPI change agents did not believe they could determine problems and solutions for the new solution by themselves. They used tactics to work in close collaboration with strategic users of the new process and they tried to solve conflicts, not only as they occurred but also through preventive actions. The two SPI change agents used tactics combining facilitating participation and political agency (Kautz et al. 2001). The tight and focused collaboration between SPI change agents and the reference group is identified by Rogers as one of five key features for SPI change agents to succeed in securing adoption of the innovation.

The two SPI change agents identified a reference group consisting of (probable) individuals from the early majority, who could become natural references and facilitate for the rest of the early majority to cross the chasm (Moore 2002; Rogers 2003). This is closely related to the important selection of the first pin in the down-the-bowlingalley tactic (Moore 1999). Having individuals in a reference group that do not want to overthrow the current way of working before they feel convinced requires special treatment. The identification of the first pin is, according to Moore, crucial. Moore claims that every other pin is derived from this head pin. In this study, we have identified the importance of the reference group in capturing new users. The reference group members defended and explained the solution and they became well-established references. The selection of the reference group has been crucial for crossing the chasm. Most users were derived from the reference group. The SPI change agents also used tactics for collaboration with the individuals in the reference group, both one by one and in the group, to manage the special needs each reference group member had. This part of the tactic supports Moore's ideas about building up a momentum where one pin helps to knock the next one over (see Figure 2). Furthermore, the SPI change agents collaborated with the reference group to listen, understand and identify the key features for the users to be willing to use the solution. This part of the tactic is well aligned with Moore's (1999) identification of "the whole product." SPI is a special instance of diffusion of innovations and the guerilla tactic is partly an instance of the down-thebowling-alley tactic. Table 9 explains how the down-the-bowling-alley and guerrilla tactics relate to each other.

Data from Table 5 shows a high correlation between high use of guerrilla tactics and high acceptance of the solution suggested by the SPI change agents. The reference 
Table 9. The Relations Between Down-the-Bowling-Alley and Guerrilla Tactics

\begin{tabular}{|l|l|l|}
\hline \multirow{1}{*}{$\begin{array}{l}\text { (Moore 2002) } \\
\text { (Each market niche, or group of } \\
\text { would-be adopters, is represented } \\
\text { by a bowling pin and the goal is } \\
\text { to strike down one pin so that it } \\
\text { helps to knock the next one over.) }\end{array}$} & $\begin{array}{l}\text { Down the Bowling Alley } \\
\text { (Identification and collaboration } \\
\text { with respected practitioners who } \\
\text { can understand and appreciate the } \\
\text { new practice and become natural } \\
\text { references for the majority of } \\
\text { users.) }\end{array}$ \\
\hline $\begin{array}{l}\text { How to } \\
\text { fhoose } \\
\text { group }\end{array}$ & $\begin{array}{l}\text { Choose an initial pin with a } \\
\text { compelling need for the solution. } \\
\text { Assure scarce competition in the } \\
\text { selected pin area. }\end{array}$ & $\begin{array}{l}\text { Choose a dedicated reference } \\
\text { group that will become natural } \\
\text { references for the majority of } \\
\text { potential users. } \\
\text { The reference group needs to } \\
\text { consist of members that cover all } \\
\text { affected organizational areas. } \\
\text { A typical member of the } \\
\text { reference group is experienced in } \\
\text { the change area, understands the } \\
\text { big picture and is well known and }\end{array}$ \\
respected.
\end{tabular}

group meetings that were prepared through individual collaboration resulted in a more positive results than those which had not. The success of a decision meeting consisted of a tendency to agree on important issues in order to proceed. Table 7 shows a regular growth of users in the ClearQuest tool since the start and five months after the rollout: 65 individuals have been captured (i.e., have started to use the solution). To capture the whole group up to early majority, 76 individuals are needed according to Rogers' percentages (see Table 8). The early majority was achieved five months after the rollout. These data indicate that the chasm has been crossed. Note that these numbers do not visualize individuals that only read information in the tool.

The users' responses to the new solution have been generally positive (see Table 6). There has been no identified turmoil requiring extra, unplanned efforts to manage 
reactions to change or to capture the early majority group. The reference group has been working in the daily business where the new solution has been used and they have been able to function as natural references for the rest of the early majority group. Not one single project or line manager expressed dissatisfaction with the solution during rollout. The chasm was successfully crossed and the new solution was implemented and used, which indicates SPI success (DeLone and McLean 1992). The study indicates that the guerrilla tactic had a positive impact on the SPI outcome (i.e., there are specific tactics that SPI change agents can use to cross the chasm).

There are a number of factors, other than the guerrilla tactic, that could have influenced the outcome of the SPI initiative in a positive direction. Two experienced SPI change agents led the work, which is an important success factor (Humphrey 1989). The SPI change agents also had previous experience with the ClearQuest tool. Most change-request processes defined in the organization over the years have had the same basic features, which could indicate that this is a relatively non-political improvement area. Furthermore, the use of a tool can itself be an enforcing factor. There is no way to bypass the process, since all information is handled within the tool. The presence of both the non-political improvement area and the organization's wish for a common solution indicate a strong pull from the practitioners (Börjesson and Mathiassen 2004b) Further research is necessary to identify the impacts of these factors.

Practitioners and researchers are advised to try out and study further tactics that SPI change agents can use to cross the chasm. We need to understand and learn more about the perils of the chasm to accomplish successful implementation and use of new innovations.

\section{CONCLUSIONS}

This research focuses on an SPI tactic to accomplish successful SPI implementation. The study carefully analyzes an SPI initiative within Ericsson AB to improve the change-request process and tool. Moore's (2002) chasm is used as a framework from which a special SPI change agent tactic, called the guerrilla tactic, is adopted. The guerrilla tactic identifies how SPI change agents can choose a target group and meet its requirements to cross the chasm. The authors view the guerilla tactic as a specific instance of Moore's down-the-bowling-alley tactic, which SPI change agents can use to assure successful SPI implementation. The result from measurements based on tool use, interviews with practitioners, and extensive participation by SPI change agents in the initiative indicates that the use of the guerrilla tactic facilitated crossing the dangerous chasm and made successful SPI implementation possible. Further research is necessary to understand and learn more about the use of different SPI change-agent tactics for crossing the chasm.

\section{REFERENCES}

Abrahamsson, P. "Rethinking the Concept of Commitment in Software Process Improvement." Scandinavian Journal of Information Systems (13), 2001, pp. 69-98. 
Andersson, I., and Nilsson, K. "Improving Diffusion Practices in a Software Organization," in Proceedings of the $35^{\text {th }}$ Annual Hawail International Conference on System Science, Volume 8, IEEE Computer Society Press, Los Alamitos, CA, 2002.

Bach, J. "Enough About Process: What We Need Are Heroes," IEEE Sofiware (12:2), 1995, pp. 96-98.

Bartunek, J. M., and Louis, M. R. Insider/Outsider Team Research, Qualitative Research Methods, Thousand Oaks, CA: Sage Publications, 1996.

Baskerville, R., Levine, L., Pries-Heje, J., Ramesh, B., and Slaughter, S. "How Internet Software Companies Negotiate Quality," IEEE Computer (14:5), 1999, pp. 51-57.

Baskerville, R., and Pries-Heje, J. "Grounded Action Research: A Method for Understanding IT in Practice," Management and Information Technology (9), 1999, pp. pp. 1-23.

Bollinger, T. B., and McGowan, C. "A Critical Look at Software Capability Evaluations," IEEE Software (8:4), 1991, pp. 25-41.

Börjesson, A. "Improve by Improving the Improvers," paper presented at the $27^{\text {th }}$ Information Systems Research in Scandinavia Working Conference on Learn, Know and Move IT, Falkenberg, Sweden, 2004.

Börjesson, A., and Mathiassen, L. "Organization Dynamics in Software Process Improvement: The Agility Challenge," in IT Innovation for Adaptablity and Competitiveness, B. Fitzgerald and E. Wynn (Eds.), Boston: Kluwer Academic Publishers, 2004a, pp. 135-156.

Börjesson, A., and Mathiassen, L. "Successful Process Implementation," IEEE Software (21:4), 2004b, pp. 36-44.

Davison, R., Maris, M. and Kock, N. "Principles of Canonical Action Research," Infomation Systems Journal (14), 2004, pp. 65-86.

Delone, W., and McLean, E. "Information Systems Success: The Quest for the Dependent Variable,"Information Systems Research (3:1), March 1992), pp. 60-95.

Eason, K. Information Technology and Organizational Change, London: Tyler \& Francis, 1988.

Fayad, M. E., and Laitinen, M. "Process Assessment Considered Wasteful," Communications of the ACM (40:11), 1997, pp. 125-128.

Fichman, R. G., and Kemerer, C. F. "The Illusory Diffusion of Innovation: An Examination of Assimlation Gaps," Information Systems Research (10:3), 1999, pp. 255-275.

Fowler, P., and Levine, L. "Technology Transition Pull: A Case Study of Rate Monotonic Analysis, Part 2," Working Paper CMU/SEI-93-TR-031, ADA275637, Software Engineering Institute, Carnegie Mellon University, 1993.

Galliers, R. D. "Choosing an Information Systems Research Approach," in Information Systems Research: Issues, Methods, and Practical Guidelines, R. D. Galliers (Ed.), Oxford: Blackwell Scientific Publications, 1992, pp. 144-162.

Grady, R. B. Successful Software Process Improvement, Upper Saddle River, NJ: Prentice Hall, 1997.

Holmberg, L., and Mathiassen, L. "Survival Patterns in Fast-Moving Software Organizations.," IEEE Software (18:6), 2001, pp. 51-55.

Humphrey, W. S. Managing the Sofmare Process, Reading, MA: Addison Wesley, 1989.

Humphrey, W. S., and Curtis, B. "Comments on a Critical Look at Software Capability Evaluations," IEEE Software (8:4), 1991, pp. 42-46.

Kautz, K., Hansen, H. W., and Thaysen, K. "Understanding and Changing Software Organisations: An Exploration of Four Perspectives on Software Process Improvement," in Diffusing Software Product and Process Innovations, M. A. Ardis and B. L. Marcolin (Eds.), Boston: Kluwer Academic Publishers, 2001, pp. 87-109.

Lyytinen, K., and Rose, G. M. "Disruptive Nature of Information Technology Innovations: The Case of Internet Computing in Systems Development Organizations," MIS Quarterly (27:4), December 2003, pp. 557-595. 
Mathiassen, L. "Collaborative Practice Research," Infonmation, Technology \& People (15:4), 2002, pp. 321-345.

McFeeley, B. "IDEAL. A User's Guide for Software Process Improvement," Handbook CMU/SEI-96-HB-001, The Software Engineering Institute, Carnegie Mellon University, 1996.

Moore, G. Crossing the Chasm: Marketing and Selling Technology Products to Mainstream Customers (revised ed.), New York: HarperCollins Publishers, 2002

Moore, G. Inside the Tornado: Marketing Strategies from Silicon Valley's Cutting Edge (revised ed.), New York: HarperCollins Publishers, 1999.

Paulk, M. C. "Structured Approaches to Managing Change," Crosstalk-The Jounalof Defense Software Engineering (12:11), 1999, pp. 4-7.

Paulk, M. C., Weber, C. V., Curtis, B., and Crissis, M. B. The Capability Maturity Model. Guidelines for Improving the Software Process, Reading, MA: Addison-Wesley, 1995.

Pries-Heje, J., and Tryde, S. "Diffusion and Adoption of IT Products and Processes in a Danish Bank," in Diffusing Software Product and Process Innovations. M. A. Ardis and B. L. Marcolin (Eds.), Boston: Kluwer Academic Publishers, 2001, pp. 17-34.

Rogers, E. M. Diffusion of Innovations ( $5^{\text {th }}$ ed.), New York: Free Press, 2003

Susman, G., and Evered, R. "An Assessment of the Scientific Merits of Action Research," Administrative Science Quarterly (23), 1978, pp. 582-603.

Weinberg, G. M. Quality Software Management Volume IV: Anticipating Change, New York: Dorset House Publishing, 1997.

Yin, R. Case Study Research, Newbury Park, CA: Sage Publications, 1994

\section{ABOUT THE AUTHORS}

Anna Börjesson is a software process improvement manager at Ericsson $\mathrm{AB}$ in Gothenburg, Sweden, and an industrial Ph.D. student at the IT University in Gothenburg. She has over 10 years of software engineering working experience, with more than 7 years been dedicated to SPI, change management and diffusion of innovations. Anna is a member of IEEE and ACM. She can be reached at anna.borjesson@ericsson.com.

Fredrik Martinsson is a software process improvement manager at Ericsson $A B$ in Gothenburg, Sweden. Fredrik is in parallel working as a change agent with special focus on requirements management, change request handling and project management. He has been working both for Ericsson and for Volvo Trucks with quality assurance, change management, and SPI. Fredrik can be reached at fredrik.martinsson@ericsson.com.

Magnus Timmerås is an SPI change agent at Ericsson AB in Gothenburg, Sweden. Magnus has nearly 10 years of experience working with SPI and SPI-related areas. Magnus has been appointed a senior engineer within SPI and his engineering skills cover areas such as CMM, RUP, software metrics, quality assurance, process adaptation work, and process implementation theories. He can be reached at magnus.timmeras@ericsson.com. 